\title{
Modulation of Middle Ear Epithelial Function by Steroids: Clinical Relevance
}

\author{
CHING-TING TAN, ${ }^{1,2}$ B. ESCOUBET, ${ }^{3}$ T. VAN DEN ABBEELE, ${ }^{1}$ G. FRIEDLANDER, ${ }^{3}$ \\ P. TRAN BA HUY, ${ }^{1}$ and P. HERMAN' \\ From the ${ }^{1}$ Laboratoire d'Otologie Expérimentale, Faculté Lariboisière-St-Louis, Université Paris VII, Paris, France, \\ ${ }^{2}$ Department Otolaryngology, National Taiwan University Hospital, Taipei, Taiwan, and ${ }^{3}$ Department of Physiology, \\ INSERM U 426, Faculté Xavier Bichat, Université Paris VII, Paris, France
}

\begin{abstract}
Ching-Ting Tan, Escoubet B, Van den Abbeele T, Friedlander G, Tran Ba Huy P, Herman P. Modulation of middle ear epithelial function by steroids: clinical relevance. Acta Otolaryngol (Stockh) 1997; 117: 284-288.

The efficacy of steroid therapy for the treatment of otitis media in children remains controversial, and a putative modulation of the middle ear epithelial function has to be demonstrated. Using the MESV cell line, short-circuit current $\left(\mathrm{I}_{\mathrm{SC}}\right)$ technique was used to evaluate changes in ion transport induced by glucocorticoids. Dexamethasone (DXM) produced a dose- and time-dependent increase in $\mathrm{I}_{\mathrm{SC}}$ in MESV cells. This effect was inhibited by specific glucocorticoid antagonist (RU-38486) and was related to a sodium transport, since the DXM-induced increase in $\mathrm{I}_{\mathrm{SC}}$ could be prevented or abolished i) by apical addition of the specific $\mathrm{Na}^{+}$channel inhibitor benzamil; or ii) by substitution of sodium with N-Methyl-glucamine in the incubation medium. RNase protection assay revealed that DXM increased the expression of the $\alpha$ subunit sodium channel mRNA, which changes paralleled the modulation of ion transport. These data demonstrate that steroids up-regulate the trans-epithelial sodium transport in the middle ear epithelium. As far as these experimental data can be extrapolated to the in vivo situation, a component of the beneficial effect of steroid therapy for the treatment of otitis media may result from a corticosteroid-induced improvement in fluid clearance from the middle ear. Key words: short-circuit current technique, steroids, otitis media, fluid clearance.
\end{abstract}

\section{INTRODUCTION}

The middle ear epithelium has been found to possess active sodium transport, in primary cultures (1) as well as in SV40-transformed middle ear epithelial cells (2). The removal of solutes from apical fluid is of importance for the efficiency of the mucociliary clearance as well as for the dry-out of the middle ear cavities.

The efficacy of steroid therapy for the treatment of otitis media in children remains controversial $(3,4)$, and a putative modulation of the middle ear epithelial function has to be demonstrated.

Using the MESV cell line, short-circuit current $\left(I_{s c}\right)$ technique was used to evaluate changes in ion transport induced by glucocorticoids. Dexamethasone (DXM) produced a dose- and time-dependent increase in $I_{s c}$ in MESV cells. This effect was inhibited by specific glucocorticoid antagonist (RU-38486) and was related to a sodium transport, since the DXM-induced increase in $\mathrm{I}_{\mathrm{sc}}$ could be prevented or abolished $i$ ) by apical addition of the specific $\mathrm{Na}^{+}$channel inhibitor benzamil; or ii) by substitution of sodium with N-Methylglucamine in the incubation medium. RNase protection assay revealed that DXM increased the expression of the $\alpha$ subunit sodium channel mRNA, which changes paralleled the modulation of ion transport. These experiments evidence a direct effect of steroids on the middle ear epithelium and support the use of steroids in the treatment of chronic otitis.

\section{MATERIALS AND METHODS}

\section{Cell culture}

Techniques have been described elsewhere (2). Briefly, MESV cells were cultured in a humidified $5 \% \mathrm{CO}_{2}$ incubator at $37^{\circ} \mathrm{C}$ in a DMEM/medium 199 mixture supplemented with $5 \%$ fetal calf serum, hydrocortisone and growth factors. All experiments were performed after 4 days of steroid deprivation and $24 \mathrm{~h}$ serum and growth factor deprivation. For electrophysiological measurements, confluent MESV monolayers were trypsinized and plated $\left(10^{5} \mathrm{cells} / \mathrm{cm}^{2}\right)$ onto $0.4 \mu \mathrm{m}$-pored tissue culture-treated polycarbonate filters (Transwell, Costar, Cambridge, MA).

\section{Bioelectric measurements}

Cells were used 6 to 7 days after seeding. Filters were mounted into Ussing chambers perfused with a $95 \%$ $\mathrm{O}_{2}-5 \% \quad \mathrm{CO}_{2}$ gas-lifted Ringer's solution chambers were connected to a voltage-current clamp device (DVC1000, World Precision Instruments, New Haven, England). When ionic substitutions were performed, sodium was substituted with $\mathrm{N}$-methyl-glucamine (NMGA), and chloride was substituted with gluconate.

Measurement of the ouabain-sensitive ${ }^{86} \mathrm{Rb}$ uptake The ouabain-sensitive $\mathrm{Rb}$ influx was used as an indicator of $\mathrm{Na}^{+}, \mathrm{K}^{+}$-ATPase activity (5). MESV cells were incubated for $24 \mathrm{~h}$ in the presence of dexa- 
methasone $\left(10^{-7} \mathrm{M}\right)$ and/or benzamil $\left(10^{-6} \mathrm{M}\right)$ or as control. Uptake measurements were performed at $37^{\circ} \mathrm{C}$ in a solution derived from Eagle's Essential Medium. Uptake was performed for 5 min with ${ }^{86} \mathrm{Rb}$ in the basal compartment. Radioactivity was extracted by Triton X-100 (1\%) and counted in a scintillation counter. Protein content of each filter was determined, and results were expressed as ng ${ }^{86} \mathrm{Rb} / \mathrm{mg}$ prot.

\section{$R$ Nase protection assay}

RNase protection assay was performed as described earlier (6). MESV monolayers were incubated for $48 \mathrm{~h}$ in the presence of increasing concentrations of dexamethasone. Total RNA equivalent of $10^{6}$ cells or yeast tRNA (tRNA, Boehringer) were hybridized with $5.10^{5} \mathrm{CPM}$ (for the human epithelial sodium channel, hENaC) and 5.10 $\mathrm{CPM}$ (for rat glyceraldehyde 3P deshydrogenase, GAPDH) radiolabeled probes at $50^{\circ} \mathrm{C}$ overnight, and RNase digestion (RNase A, $40 \mu \mathrm{g} / \mathrm{ml}$ and $\mathrm{T} 1,2 \mu \mathrm{g} / \mathrm{ml}$, from Boehringer) was performed at $30^{\circ} \mathrm{C}$ for $60 \mathrm{~min}$. Then, digestion by proteinase $\mathrm{K}(125 \mu \mathrm{g} / \mathrm{ml}$ Boehringer $)$ was done at $37^{\circ} \mathrm{C}$ for $30 \mathrm{~min}$. After phenol extraction and ethanol precipitation, protected fragments were separated by gel electrophoresis. Gels were analyzed with an Instant Imager (Packard Instrument Company, CT).

\section{cRNAs probes}

Preliminary experiments were performed to validate the cross-reactivity between the human epithelial sodium channel probe and gerbil mRNA. A $110 \mathrm{bp}$ fragment was recovered. Antisense RNA probes were synthetized from the translated region of the $\alpha$ subunit (1036-1259) of hENaC. The cRNA synthesis (Promega kit) was done using ${ }^{32}$ P-UTP (Amersham, specific activity $>15 \mathrm{TBq} / \mathrm{mmol}$ ). The ${ }^{32} \mathrm{P}$-cRNA probe was 307 base pairs and the protected fragment in gerbil was approximately 110 base pairs. Rat glyceraldehyde 3P deshydrogenase (GAPDH) mRNA was used for standardization.

$\alpha-h E N a C$ subunit cDNA was a gift from Richard Boucher (Chapel Hill, NC) and GAPDH cDNA from C. Dani (Nice, France).

\section{Reagents}

Hydrocortisone, transferrin, triiodothyronine, insulin, EGF, ouabain, N-Methyl-glucamine, sodium gluconate, EDTA, were purchased from Sigma Chemical (St. Louis, MO). DMEM, medium-199, penicillin/ streptomycin, HEPES and glutamine were from TechGen (Les Ulis, France). FCS was purchased from GibcoBRL (Life Technologies, UK). Benzamil was from Research Biochemical Incorporated (Nat- ick, MA), RU-38486 was a gift from Roussel UCLAF Pharmaceuticals (Romainville, France). All other chemicals were of analytical grade.

\section{Statistical analysis}

Results were expressed as mean \pm S.E.M. of $n$ separate experiments. Comparisons of means were performed by using one or two-way analysis of variance (as appropriate) followed by Fisher's least significant difference or Dunnett's test for comparison from control. Differences were considered significant at $p<0.05$.

\section{RESULTS}

Effect of steroids on $I_{s c}$

Incubation for $48 \mathrm{~h}$ in the presence of dexamethasone $\left(10^{-7} \mathrm{M}\right)$, a glucocorticoid agonist, increased $\mathrm{I}_{\mathrm{sc}}$ from $0.71 \pm 0.05 \mu \mathrm{A} / \mathrm{cm}^{2}$ to $2.06 \pm 0.07 \mu \mathrm{A} / \mathrm{cm}^{2}(p<0.01$, $n=6$, Fig. $1 A$ ). The time-course of this effect evi-

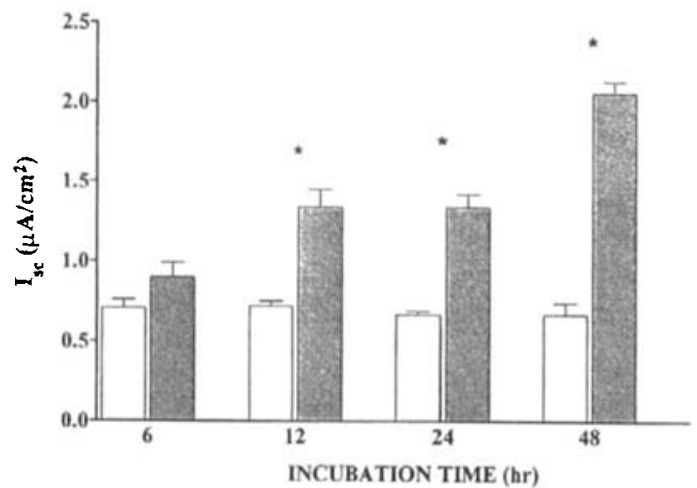

(A)

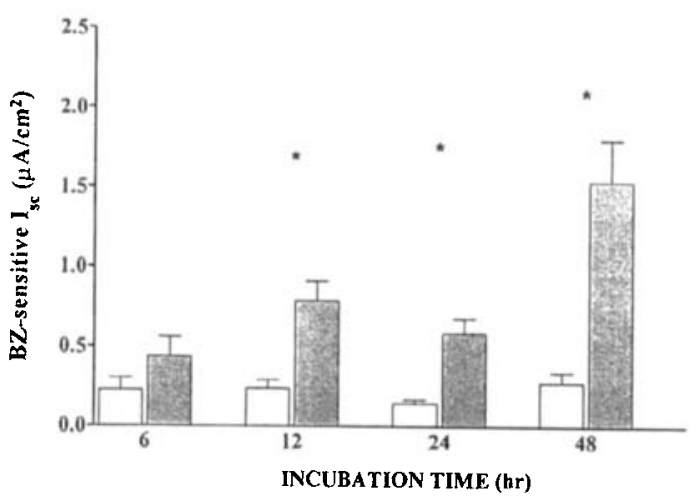

(B)

Fig. 1. Time-response relationship of DXM on $\mathrm{I}_{\mathrm{sc}}$ of MESV monolayers. (A) Steady-state $\mathrm{I}_{\mathrm{sc}}$ was measured in control (CTL, empty bars) and in monolayers exposed to dexamethasone (DXM, $10^{-7} \mathrm{M}$, hatched bars). (B) In the same conditions, the benzamil-sensitive $I_{s c}$ is reported, calculated as the difference between steady-state $I_{s c}$ and the value measured after addition of benzamil $\left(10^{-6} \mathrm{M}\right)$ to the apical compartment.

* Significantly different from control $(p<0.05, n=6)$. 


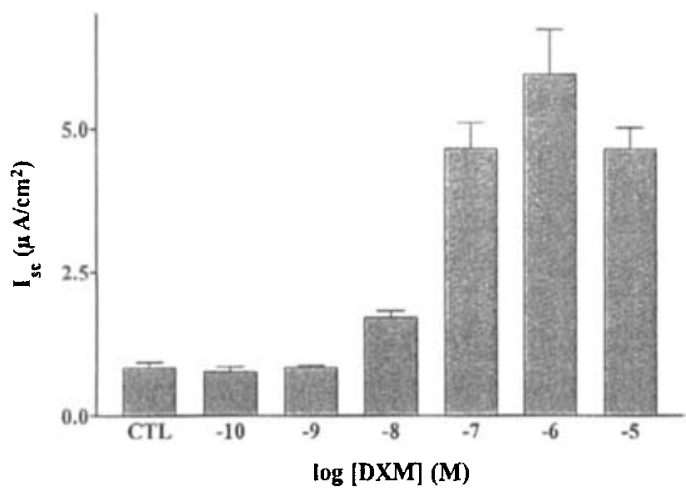

Fig. 2. Dose-response relationship of DXM on short-circuit current of MESV monolayers. MESV monolayers were incubated for $24 \mathrm{~h}$ in the presence of increasing concentrations of DXM (from $10^{-10}$ to $10^{-5} \mathrm{M}$ ) before measurement of the steady-state $\mathbf{l}_{\mathrm{sc}}$. Values are means \pm S.E.M. $(n=4-8)$

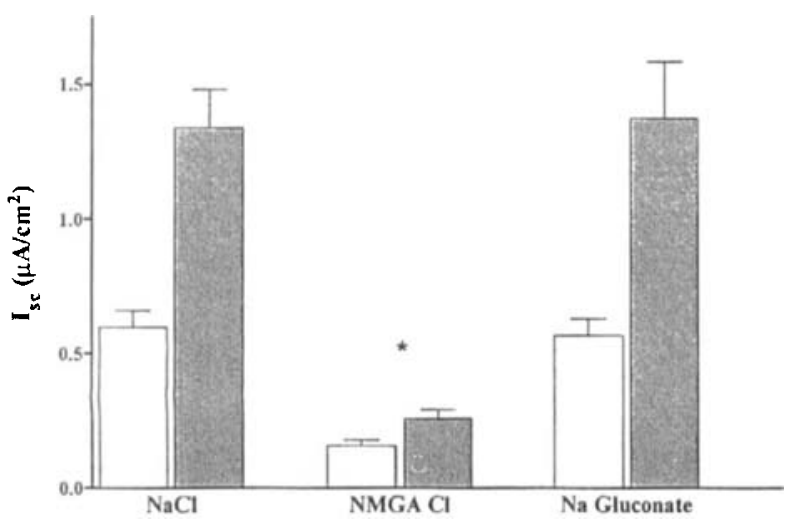

Fig. 3. Incidence of ion substitutions on the effect of DXM on $\mathrm{I}_{\mathrm{sc}}$. MESV monolayers were incubated for $24 \mathrm{~h}$ as control (empty bars) or in the presence of DXM $\left(10^{-7} \mathrm{M}\right.$, hatched bars). Subsequently, $I_{\mathrm{sc}}$ was measured either in a modified Ringer solution ( $\mathrm{NaCl}$ ), or in the same solution in which sodium was substituted with a non-permeant cation (NMGA $\mathrm{Cl}$ ) or chloride with a non-permeant anion ( $\mathrm{Na}$ gluconate). * No significant difference between control and DXMtreated monolayers.

denced a significant increase starting at $12 \mathrm{~h}$. Increasing concentrations of dexamethasone from $10^{-10}$ to $10^{-5} \mathrm{M}$ for a $24 \mathrm{~h}$ incubation induced a concentration-dependent increase in $\mathrm{I}_{\mathrm{sc}}$, from $0.84 \pm 0.09 \mu \mathrm{A} /$ $\mathrm{cm}^{2}$ for control up to $5.97 \pm 0.77$ in the presence of a
Table II. Effect of dexamethasone on the ouabain-sensitive ${ }^{86} \mathrm{Rb}$ uptake

The $\mathrm{Na}^{+}, \mathrm{K}^{+}$-ATPase activity was determined as the ouabain-sensitive rubidium uptake in monolayers treated or not with DXM $\left(10^{-7} \mathrm{M}\right)$ for $24 \mathrm{~h}$, without $(\mathrm{BZ}-)$ or with benzamil $\left(10^{-6} \mathrm{M} ; \mathrm{BZ}+\right)$ in the bath during the incubation period.

Ouabain-sensitive

${ }^{86} \mathrm{Rb}$ uptake (pg/mg prot) CTL DXM

$\mathrm{BZ}-\quad 35.10 \pm 5.10 \quad 54.50 \pm 6.20^{*}$

$\mathrm{BZ}+\quad 34.40 \pm 5.90 \quad 34.20 \pm 6.40$

* Significant difference between DXM-treated and control monolayers $(p<0.05, n=5)$.

$10^{-6} \mathrm{M}$ concentration of DXM $(n=6)$. The resulting concentration of half maximal stimulation (EC50) was $2.68 \times 10^{-8} \mathrm{M}$ (Fig. 2).

Addition of benzamil (10-6 [7]), a specific sodium channel blocker to the apical side of MESV monolayers blunted the effect of DXM (Fig. 1B). The DXMinduced increase in $I_{\mathrm{se}}$ was further characterized by ionic substitutions with non-permeant ions. The DXM effect on Isc was preserved when chloride was substituted with gluconate; on the contrary, replace-

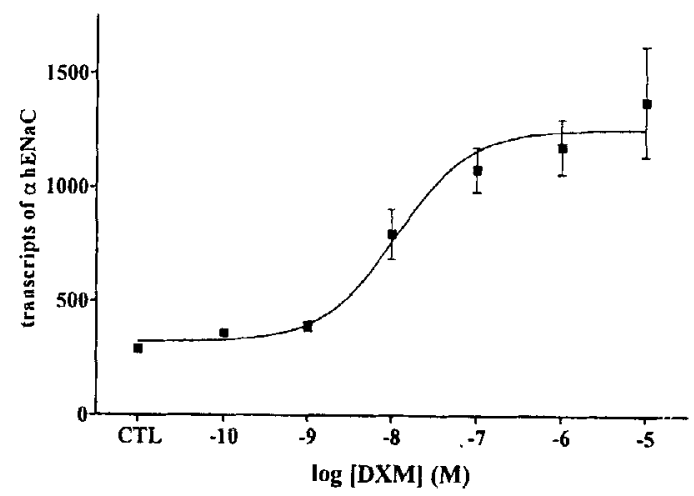

Fig. 4. Modulation by dexamethasone of the expression of transcripts of the $\mathrm{Na}^{+}$channel. RNase protection assay measured the amount of mRNA encoding the $\alpha$ subunit of the epithelial sodium channel on MESV monolayers incubated in the presence of increasing concentrations of dexamethasone (arbitrary units).

\section{Table I. Effect of $R U-38486$ on the DXM effect on $I_{s c}$}

Cells were grown to confluence on Transwell filters, and incubated as control (CTL) or in the presence of dexamethasone (DXM, $10^{-7} \mathrm{M}$ ) for $24 \mathrm{~h}$, with or without increasing concentrations of the glucocorticoid antagonist RU-38486.

\begin{tabular}{lllllll}
\hline Incubation & $\mathrm{CTL}$ & $\mathrm{DXM}$ & $\begin{array}{l}\mathrm{DXM}+\mathrm{RU} \\
\left(10^{-8} \mathrm{M}\right)\end{array}$ & $\begin{array}{l}\mathrm{DXM}+\mathrm{RU} \\
\left(10^{-7} \mathrm{M}\right)\end{array}$ & $\begin{array}{l}\mathrm{DXM}+\mathrm{RU} \\
\left(10^{-6} \mathrm{M}\right)\end{array}$ & $\begin{array}{l}\mathrm{DXM}+\mathrm{RU} \\
\left(10^{-5} \mathrm{M}\right)\end{array}$ \\
\hline $\begin{array}{l}\mathrm{I}_{\mathrm{sc}} \\
\left(\mu \mathrm{A} / \mathrm{cm}^{2}\right)\end{array}$ & $0.68 \pm 0.02^{*}$ & $1.22 \pm 0.06$ & $1.21 \pm 0.06$ & $1.00 \pm 0.04^{*}$ & $0.86 \pm 0.06^{*}$ & $0.90 \pm 0.04^{*}$ \\
\hline
\end{tabular}

\footnotetext{
* Significantly different from the DXM condition $(p<0.05, n=6)$.
} 
ment of sodium with N-Methyl-glucamine blunted the increase in $I_{s c}$ (Fig. 3). The specificity of the glucocorticoid effect was assessed by inhibition of the DXM effect by increasing concentrations of the selective antagonist RU-38486 (Table I). MESV monolayers were incubated for $24 \mathrm{~h}$ in the presence of DXM $\left(10^{-7} \mathrm{M}\right)$ and increasing concentrations $\left(10^{-8} \mathrm{M}\right.$ to $10^{-5} \mathrm{M}$ ) of RU-38486, which resulted in a dose-dependent decrease in the effect of DXM.

\section{Measurement of ouabain-sensitive ${ }^{86}$ Rb uptake}

The effect of DXM was investigated on intact cells by the ouabain-sensitive ${ }^{86} \mathrm{Rb}$ uptake. Incubation with DXM $\left(10^{-7} \mathrm{M}\right.$ for $\left.24 \mathrm{~h}\right)$ increased the ouabain-sensitive rubidium uptake from $35.1 \pm 5.1 \mathrm{pg} / \mathrm{mg}$ prot/ $5 \mathrm{~min}$ in control to $54.5 \pm 6.2 \mathrm{pg} / \mathrm{mg}$ prot $/ 5 \mathrm{~min}$ $(p<0.05 ; n=5)$. Coincubation with benzamil $\left(10^{-6} \mathrm{M}\right)$ prevented this effect since the ouabain-sensitive rubidium uptake was $34.4 \pm 5.9 \mathrm{pg} / \mathrm{mg}$ prot in control and $34.2 \pm 5.4 \mathrm{pg} / \mathrm{mg}$ prot $/ 5 \mathrm{~min}$ in DXMtreated cells (Table II).

\section{Effect of steroid treatment on $m R N A$ level of the $\alpha$ subunit of the $\mathrm{Na}^{+}$channel}

The ${ }^{86} \mathrm{Rb}$ uptake experiments suggested that the apical sodium entry was the primary target of the steroid effect. Therefore we investigated whether steroids might directly modulate the transcription of apical transporters. The level of expression of the mRNA encoding the $\alpha$ subunit of the sodium channel paralleled the increase in the concentration of DXM. The kinetics of this process was sigmoidal. The resulting concentration of half-maximal stimulation was $1.13 \times 10^{-8} \mathrm{M}$ (Fig. $4, n=4$ ).

\section{DISCUSSION}

This work supports the use of glucocorticosteroids in the treatment of otitis media. Steroids directly modulate sodium transport across the middle ear epithelium, through an increase in the transcription of sodium channels. This process might allow dry-out of the middle ear cavities and enhance the healing process in the course of chronic otitis.

\section{Steroids enhance sodium transport across the middle ear epithelium}

Previous experiments demonstrated the role of apical amiloride-sensitive sodium channels and basolateral $\mathrm{Na}^{+}, \mathrm{K}^{+}$-ATPase in the genesis of a trans-epithelial sodium transport, which in turn drives a trans-epithelial water flow (1). Incubation in the presence of dexamethasone, a major glucocorticosteroid agonist, increased dramatically the electrogenic ion transport across the middle ear epithelium (Fig. 1A). Sodium transport mainly accounts for this increase since $(i)$ the increase in $I_{s c}$ was primarily related to a benzamilsensitive current (Fig. 1B); and (ii) replacing sodium on both sides of the epithelium by a non permeant cation abolished the steroid effect (Fig. 3), which was preserved when chloride was substituted with gluconate.

The trans-epithelial ion transport rate was measured by the ouabain-sensitive ${ }^{86} \mathrm{Rb}$ uptake, which indirectly reflects sodium extrusion across the basolateral membrane. As shown in Table II, while DXM increased the ouabain-sensitive $\mathrm{Rb}$ uptake, this increase was blunted in the presence of benzamil, which precludes a primary modulation of $\mathrm{Na}^{+}, \mathrm{K}^{+}$-ATPase. On the contrary, the effect of benzamil suggests an intrinsic effect of glucocorticosteroids on the apical sodium entry, followed by a secondary increase in $\mathrm{Na}^{+}, \mathrm{K}^{+}$-ATPase activity.

\section{The increase in sodium transport is related to an increase of the expression of transcripts encoding for the a subunit of the epithelial sodium channel}

The epithelial sodium channel has recently been cloned and consists of three separate subunits designated as $\alpha, \beta, \gamma$ which combine to form a highly selective pore (for review, see [8]). Sodium channel regulation may occur through alterations in channel kinetics, channel number, or both. In our experiments, the DXM-induced increase in mRNA encoding the $\alpha$ subunit of the epithelial sodium channel strictly paralleled the effect observed on short-circuit current, which favors a direct effect on the number of channels. Likewise, recent studies have evidenced in the pulmonary epithelium that increased $\mathrm{Na}^{+}$transport is related to increased steady-state levels of $\mathrm{Na}^{+}$ channel mRNAs and likely channel number $(8,7)$.

The putative modulation of $\beta$ and $\gamma$ subunits was not investigated in this study. However, the $\alpha$-subunit of the sodium channel exhibits, when expressed in oocytes, all the characteristics of the highly selective channel (10), while $\beta$ - and $\gamma$-subunits allow maximal activity of active sodium channels. The intensity of the modulation of sodium transport by dexamethasone in MESV cells suggests that either $\beta$ - and $\gamma$-subunits are constitutively expressed at a high level, or that these subunits are also modulated by steroids (11).

Altogether, our data suggest that cell sodium entry through the amiloride-sensitive $\mathrm{Na}$ channel is enhanced by corticosteroids, while cell $\mathrm{Na}^{+}$extrusion by $\mathrm{Na}^{+}, \mathrm{K}^{+}$-ATPase is not regulated. Indeed, it has been shown in other tight epithelia that the rate-limiting step for trans-epithelial sodium reabsorption is $\mathrm{Na}$ entry, while $\mathrm{Na}^{+}, \mathrm{K}^{+}$-ATPase adapts its activity to maintain a low intracellular sodium concentration. 
Incidence of the epithelial effect of steroids on the management of otitis media

Because of its ontogeny and morphological feature, the middle ear epithelium may be considered as a respiratory epithelium. Our data demonstrate, as for the case of lung epithelium, that steroids up-regulate the trans-epithelial sodium transport in the middle ear epithelium. These data were obtained on a middle ear cell line and require obviously a complementary assessment on primary culture and in vivo. However, as far as these experimental data can be extrapolated to the in vivo situation, a component of the beneficial effect of steroid therapy for the treatment of otitis media (3) may result from a corticosteroid-induced improvement in fluid clearance from the middle ear.

\section{ACKNOWLEDGMENTS}

The authors are grateful to Richard Boucher and Nicolette Farman for kindly providing the $\alpha-\mathrm{hENaC}$ subunit cDNA. They are also indebted to Claude Amiel for helpful discussion. This work was supported by grants from Institut National de la Santé et de la Recherche Médicale, and from Faculté Lariboisiére-St-Louis and Faculté Xavier Bichat, Université Paris 7 .

\section{REFERENCES}

1. Herman P, Friedlander G, Tran Ba Huy P, Amiel C Ion transport by primary cultures of Mongolian gerbil middle ear epithelium. Am J Physiol 1992; 262: F37380 .

2. Herman $P$, Cassingena $R$, Friedlander $G$, Soler $P$, Grodet A, Tran Ba Huy P, Amiel C. Middle ear cell line that maintains vectorial electrolyte transport. J Cell Physiol 1993; 154: 615-22.

3. Rosenfeld RM, Mandel EM, Bluestone CD. Systemic steroids for otitis media with effusion in children. Arch. Otolaryngol. Head Neck Surg 1991; 117: 984-989.
4. Stool SE, Berg AO, Berman S, et al. Managing otitis media with effusion in young children. Quick reference guide for clinicians. AHCPR Publication No. 94-0623. Rockville, MD: Agency for Health Care Policy and Research, Public Health Service, U.S. Department of Health and Human Services. July 1994.

5. Cheval L, Doucet A. Measurement of Na-K-ATPasemediated rubidium influx in single segments of rat nephron. Am J Physiol 1990; 259: F111-121.

6. Escoubet B, Coureau C, Blot-Chabaud M, Bonvalet JP, Farman N. Corticosteroid receptor mRNA expression is unaffected by corticosteroids in the rat kidney, heart and colon Am J Physiol (Cell Physiology 39) 1996; 270: C1343-53.

7. Voilley $N$, Lingueglia $\mathrm{E}$, Champigny $\mathrm{G}$, et al. The lung amiloride-sensitive $\mathrm{Na}^{+}$channel-Biophysical properties, pharmacology, ontogenesis, and molecular cloning. Proc Nat Acad Sci 1994; 91: 247-251.

8. Rossier BC, Canessa CM, Schild L, Horisberger JD. Epithelial sodium channels. Current Opin Nephrol Hypertens 1994; 3: 487-496.

9. O'Brodovich H, Canessa C, Ueda J, Rafii B, Rossier $\mathrm{BC}$, Edelson J. Expression of the epithelial $\mathrm{Na}^{+}$channel in the developing rat lung. Am J Physiol 265 (Cell Physiol) 1993; 34: C491-6.

10. Canessa CM, Schild L, Buell G, Thorons B, Rossier BC. Amiloride-sensitive epithelial $\mathrm{Na}^{+}$channel is made of three homologous subunits. Nature 1994; (Lond) 367: $463-7$.

11. Renard S, Voilley N, Bassilana F, Lazdunski M, Barbry $P$. Localization and regulation by steroids of the $\alpha$, $\beta$ and $\gamma$ subunits of the amiloride-sensitive $\mathrm{Na}^{+}$channel in colon, lung and kidney. Pfügers Arch Eur $J$ Physiol 1995; 430: 299-307.

Philippe Herman, MD, PhD

Hopital Lariboisiere

Service ORL

2, rue Ambroise Paré

F-75010 Paris

Tel: +33149958049

Fax: + 33149958063 